\title{
Effect of Provenance and Storage Agroecology on Duration of Yam (Dioscorea rotundata Poir.) Tuber Dormancy
}

\author{
Elsie Ihuakwu Hamadina ${ }^{1}$, Robert Asiedu ${ }^{2}$ \\ ${ }^{1}$ Crop and Soil Science Department, Faculty of Agriculture, University of Port Harcourt, Port Harcourt, Nigeria \\ ${ }^{2}$ International Institute of Tropical Agriculture, IITA, Ibadan, Nigeria
}

Email address:

elsieile@yahoo.com (E. I. Hamadina)

\section{To cite this article:}

Elsie Ihuakwu Hamadina, Robert Asiedu. Effect of Provenance and Storage Agroecology on Duration of Yam (Dioscorea rotundata Poir.) Tuber Dormancy. Agriculture, Forestry and Fisheries. Vol. 4, No. 3, 2015, pp. 95-100. doi: 10.11648/j.aff.20150403.13

\begin{abstract}
Crop improvement in yam is slow due to poor understanding of tuber dormancy. Tuber provenance and storage agroecology are thought to affect the duration to sprouting in yam, but systematic studies on the role of these factors are rare. The objective of this study was to determine the effects of tuber provenance and storage agroecology on the duration to sprouting in D. rotundata. Twenty landraces [comprising 7 originating from the Guinea savanna (GS), 5 from the Forest/transition (TS), and 8 from the Humid forest (HF)] were collected and multiplied at a location in their respective agroecologies: Abuja (GS), Ibadan (TS) and Onne (HF). Thereafter, 100 tubers of each of the 20 landraces were stored at each of the three sites, and dates of the appearance of shoot bud (ASB)/ sprouting were recorded. The results showed that provenance did not significantly affect the duration from planting to sprouting or the duration from date in storage to sprouting in D. rotundata. The duration to ASB varied by up to 21 days (d) for landraces originating from HF and TS, and $37 \mathrm{~d}$ for landraces originating from GS. Variations among landraces within a provenance group were greater than between provenance groups. This suggests that the provenance of a landrace is not a major factor controlling the duration to ASB. All landraces responded to storage agroecology/ environment in a similar manner. There was no interaction between provenance and storage environment. Tubers stored at Onne and Ibadan sprouted about $10 \mathrm{~d}$ earlier than those at Abuja, and this was associated with slightly higher temperature and $\mathrm{RH}$ at Onne and Ibadan. Storage agroecology is an important factor controlling the duration to sprouting but provenance is not.
\end{abstract}

Keywords: Provenance, Dioscorea Rotundata, Humid Forest, Guinea Savanna, Forest Transition

\section{Introduction}

Dormancy is an adaptive trait associated with distinct seasons that vary in time and space ([1], [2]). In yam, the timing of the end of the growing season (marked by the commencement of vine senescence) coincides with the start of the dry season. Also, these seasons are associated with the start of yam tuber dormancy while the onset of the rainy season is associated with the onset of sprouting. The association of these two events with distinct seasons of the year highlights their ecological importance.

Duration of dormancy is regulated by both endogenous and environmental mechanism(s) ([3], [4]). In yams, tuber dormancy is long (90 to $150 \mathrm{~d}$ ) and variable. Variability in the duration of dormancy has been attributed to differences in species, variety, crop management, date of tuber harvest, growth, and storage environment ([5], [6]). Many studies have been conducted to understand the endogenous and environmental mechanism(s) that regulate the duration of yam dormancy. These studies have been successful at identifying the roles of endogenous plant growth regulators (PGRs) and storage temperature on dormancy. While it is clear that PGRs and temperature can affect dormancy, their effects have been minimal [7].

One aspect of environmental control of dormancy that has been poorly studied is the effect of provenance/adaptation on the duration of dormancy. A very early indication of a possible role of agroecology of origin on differences in duration of tuber dormancy was reported by Coursey, 1976 [8] and Passam, 1982 [6]. In Coursey, 1967 [10] tubers of $D$. elephantipes grown in semi-desert area were observed to exhibit dormancy that is as long as the dry period. Also, the work by Ile, 2004 [11] suggests that $D$. cayenensis that is found more in the high rainfall ecological zone (where the growing season is long and dry season is short) has a long 
growing period and tends to sprout slightly earlier than $D$. rotundata is found more in the moist savanna. However, this assertion has not been systematically studied. Within species differences in duration of dormancy is also common but the reason for this is unclear. We ask therefore, whether the duration of dormancy in $D$. rotundata is under some ecological control determined by adaptation to growing and storage condition. Therefore, the objectives of the study were to determine the effects of tuber provenance and storage agroecology on the duration to sprouting in D. rotundata.

\section{Materials and Methods}

\subsection{Experimental Locations}

The experiments were conducted in three IITA stations located at Abuja, Ibadan, and Onne in Nigeria. These locations cut across three yam producing agroecological zones from a mid-altitude northern part to a low altitude southern part of Nigeria. Abuja, Ibadan and Onne represent the Guinea savanna (GS), Forest/ savanna (TS) and the
Humid rainforest (HF), agroecological zones respectively (Fig. 1).

Selected ecological characteristics of the above locations are presented in Table 1. The locations are different in altitude, annual total rainfall (total, duration and distribution pattern) and hence in the duration of the growing season. They are also different in annual mean relative humidity and less clearly in annual mean air temperature. However, the annual mean values for average minimum and maximum air temperatures indicate that night and day temperatures are about $1{ }^{\circ} \mathrm{C}$ warmer and cooler respectively from the north (Abuja) to south (Onne). Abuja is distinctly less humid compared to Ibadan or Onne. Rainfall pattern at Abuja and Onne are similar with a peak in September. However, it is distributed over much of the year at Onne compared to Abuja, resulting in a longer growing season at Onne (approx. $300 \mathrm{~d}$ ) than at Abuja (approx. $210 \mathrm{~d}$ ). At Ibadan, rainfall peaks in June and again in September with a break in August and the duration of the rainy/ growing season is about $270 \mathrm{~d}$

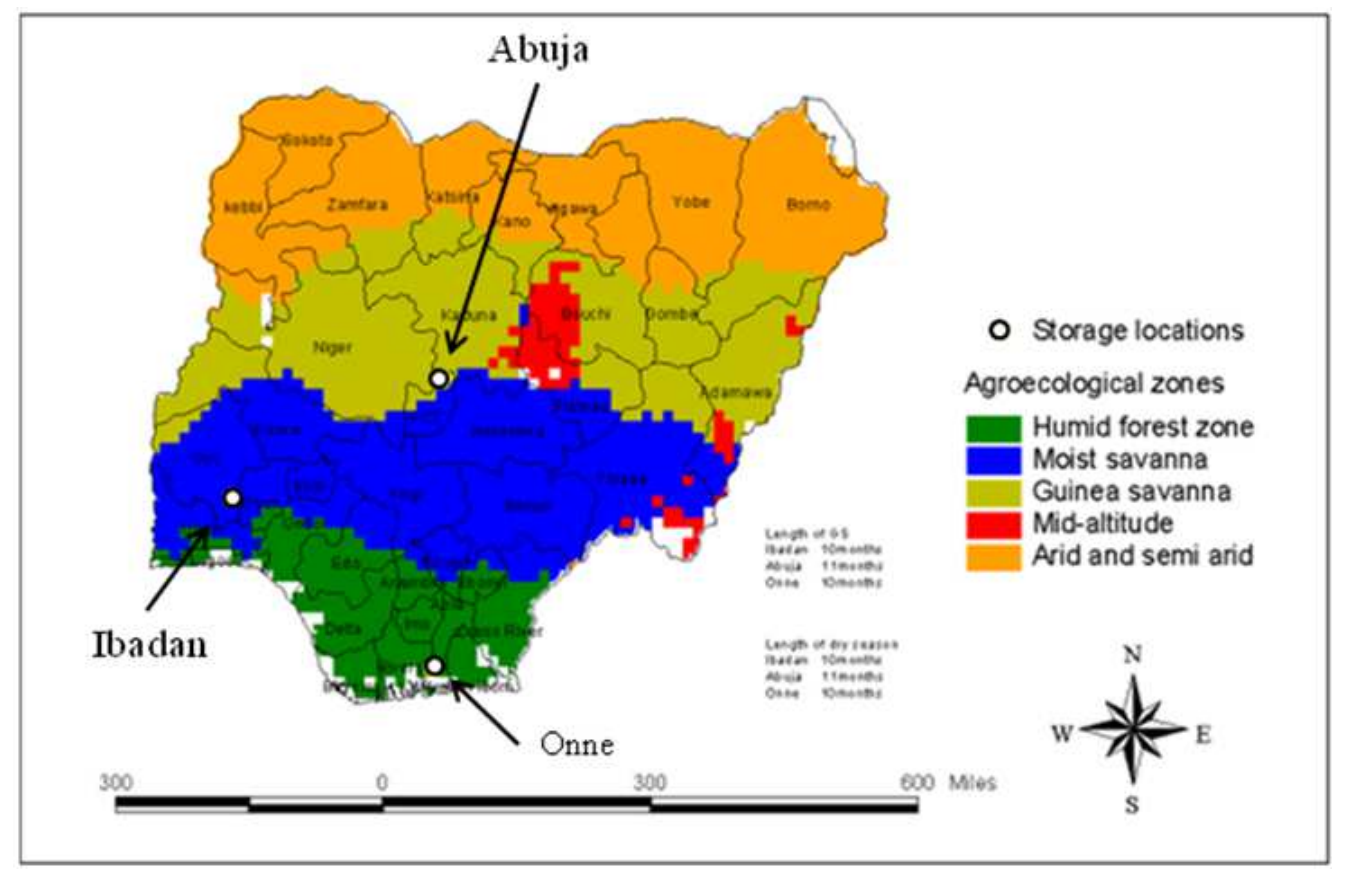

Figure 1. Agro-ecological zones in Nigeria showing study locations. Source: IITA, Ibadan, Agroecological Unit-Modified.

Table 1. Ecological characteristics of three selected locations representing the three agroecological zones in Nigeria.

\begin{tabular}{|c|c|c|c|c|c|c|c|}
\hline Location & $\begin{array}{l}\text { Co-ordinates } \\
\text { (Long., Lat.) }\end{array}$ & $\begin{array}{l}\text { Altitude } \\
\text { (m) }\end{array}$ & $\begin{array}{l}\text { Annual rainfall } \\
(\mathbf{m m})\end{array}$ & $\begin{array}{l}\text { Rainfall } \\
\text { pattern }\end{array}$ & $\begin{array}{l}\text { Annual average } \\
\text { temperature } \\
\min / \max \left({ }^{\circ} \mathrm{C}\right)\end{array}$ & $\begin{array}{l}\text { Annual average } \\
\text { relative humidity } \\
\min / \max (\%)\end{array}$ & $\begin{array}{l}\text { Duration of } \\
\text { rainy season }\end{array}$ \\
\hline Abuja & $9^{\circ} 16^{\prime} \mathrm{N} ; 7^{\circ} 20^{\prime} \mathrm{E}$ & 300 & 1302 & Unimodal & $21.3 / 33.3$ & $14.4 / 37.4$ & Apr.-Oct. \\
\hline Ibadan & $7^{\circ} 26^{\prime} \mathrm{N} ; 3^{\circ} 54^{\prime} \mathrm{E}$ & 210 & 1253 & Bimodal & $22.0 / 32.0$ & $55.6 / 87.0$ & Mar.-Nov. \\
\hline Onne & $4^{\circ} 46^{\prime} \mathrm{N} ; 7^{\circ} 10^{\prime} \mathrm{E}$ & 10 & 2400 & Unimodal & $23.0 / 31.0$ & $62.8 / 94.5$ & Feb.-Nov. \\
\hline
\end{tabular}

Source: Jagtap (1993)

\subsection{Collection of Landraces and Tuber Multiplication}

Twenty-two yam varieties (landraces) indigenous to the GS, TS and HF agroecologies were collected from farmers in each agroecology. Eight of these landraces were collected from the GS, five from the TS and seven from the HF (Table 2). Tubers were then multiplied (by planting mini-setts); landraces from GS were multiplied at Abuja while those from TS and HF were multiplied at Ibadan and Onne respectively. 
They were multiplied within their agroecology of origin to avoid any possible effects of growing location.

At Abuja, planting was done in May while at Ibadan and Onne planting was done in April. Tubers were harvested at vine senescence on December at Abuja, Onne and Ibadan respectively.

Table 2. Dioscorea rotundata landraces collected across three agroecological zones of the yam belt of Nigeria.

\begin{tabular}{|c|c|c|c|}
\hline Agro-ecological zone & Acc. No. & Local name & Co-ordinates \\
\hline Guinea savanna & Jan-99 & Giwa & 9o $22^{\prime} \mathrm{N} ; 60$ 18' E \\
\hline Guinea savanna & Feb-99 & Suba & 9 o $05^{\prime} \mathrm{N} ; 6038^{\prime} \mathrm{E}$ \\
\hline Guinea savanna & Mar-99 & Akwuki & 9 o $05^{\prime} \mathrm{N} ; 6 \mathrm{c} 38^{\prime} \mathrm{E}$ \\
\hline Guinea savanna & Apr-99 & Maisaki & 10 o $85^{\prime} \mathrm{N} ; 7 \mathrm{o} 33^{\prime} \mathrm{E}$ \\
\hline Guinea savanna & May-99 & Kpakogi & 9o $18^{\prime} \mathrm{N} ; 60$ 15'E \\
\hline Guinea savanna & Jun-99 & Yar-ganye & 10o $52^{\prime} \mathrm{N} ; 7 \mathrm{o} 34^{\prime} \mathrm{E}$ \\
\hline Guinea savanna & Jul-99 & Chikakwudu & 11o $08^{\prime} \mathrm{N} ; 7 \mathrm{o} 34^{\prime} \mathrm{E}$ \\
\hline Guinea savanna & Aug-99 & Amara & 11 о $05^{\prime} \mathrm{N} ; 7$ о $31^{\prime} \mathrm{E}$ \\
\hline Forest/ savanna & Sep-99 & Lasirin & 7o 39’N;3o 39'E \\
\hline Forest/ savanna & Oct-99 & Ajelanwa & 7o 39’N;3o 39'E \\
\hline Forest/ savanna & Nov-99 & Ayin & $7 \mathrm{o} 40^{\prime} \mathrm{N} ; 3 \mathrm{o} 45^{\prime} \mathrm{E}$ \\
\hline Forest/ savanna & Dec-99 & Ehuru & 7o $38^{\prime} \mathrm{N} ; 3 \mathrm{o} 40^{\prime} \mathrm{E}$ \\
\hline Forest/ savanna & $99-13$ & Omi-efu & 7o $38^{\prime} \mathrm{N} ; 3$ o 40’E \\
\hline Humid rainforest & $99-14$ & Ekpe & 6 o $20^{\prime} \mathrm{N} ; 60$ 50’ $\mathrm{E}$ \\
\hline Humid rainforest & $99-15$ & Adaka & 6 o $20^{\prime} \mathrm{N} ; 6$ o $50^{\prime} \mathrm{E}$ \\
\hline Humid rainforest & $99-16$ & Nwopoko & 6 o 40’'N;7o 22'E \\
\hline Humid rainforest & $99-17$ & Abi & 6 o 40’N;6o 48’ E \\
\hline Humid rainforest & $99-18$ & Obiaturugo & 5o 49’N;7o 26’ E \\
\hline Humid rainforest & $99-19$ & Azia & $4 c 43^{\prime} N ; 7018^{\prime} \mathrm{E}$ \\
\hline Humid rainforest & $99-20$ & Okom & 5o 19’ $\mathrm{N} ; 7$ o $21^{\prime} \mathrm{E}$ \\
\hline Humid rainforest & $99-21$ & Bilazia & 4o 40’'N;7o 23'E \\
\hline Humid rainforest & $99-22$ & Agbaka & $5019^{\prime} \mathrm{N} ; 7021^{\prime} \mathrm{E}$ \\
\hline
\end{tabular}

\subsection{Reciprocal Transfer of Tubers from Agroecology of Origin to Storage Locations}

Two 99-8 (from the GS) and 99-22 (from the HF) out of the 22 landraces were not included in the sprouting/storage study, thus twenty landraces were used in this study. Tubers of each landrace were divided into three groups. Each third of the groups was stored at one of the three storage locations. These transfers were completed within five days of harvest and tubers are considered as being in their various growth agroecologies until they arrive at the storage location. Thus, at each storage location, there were 20 landraces replicated 100 times; there were 100 tubers/ landrace and each tuber was considered a replicate. Individual tubers were weighed, numbered and placed in open wooden or plastic boxes, and placed on shelves in the yam barn.

\subsection{Data Collection and Analysis}

Temperature and relative humidity $(\mathrm{RH})$ in the yam barns were recorded every $2 \mathrm{~h}$ using Tinytalk ${ }^{\circledR}(2$ nos.) temperature and relative humidity sensors. These readings were taken in duplicate. Individual tubers were observed every $7 \mathrm{~d}$ for the appearance of shoot bud on the tuber surface (ASB or sprouting). The data analyzed was duration from harvest to sprouting/ASB. Data was analyzed as a complete 32 factorial experiment, consisting of three provenances (20 landraces nested in provenances) and three storage locations with individual tubers as replicates. SAS V8, GLM procedure was used to run this analysis

\section{Results}

\subsection{Temperature and Relative Humidity in the Yam Barns}

The major difference between storage locations was minimum temperature $\left({ }^{\circ} \mathrm{C}\right)$. Abuja had the coolest night temperature $\left(14.6{ }^{\circ} \mathrm{C}\right)$ while the nights were warmer by 2 and $5{ }^{\circ} \mathrm{C}$ at Ibadan and Onne respectively. Maximum and average temperatures were similar across storage locations, average temperature values were 26.2 and $26.8^{\circ} \mathrm{C}$. On the other hand, average $\mathrm{RH}$ at Abuja was $42 \%$ while it was $55 \%$ at Ibadan.

\subsection{Effects of Provenance and Storage Location on Duration from Planting to Sprouting and Storage to Sprouting}

Since planting (multiplication) date was different at Abuja compared to Onne, it was necessary to determine whether the effects of provenance and storage location on date of sprouting were confounded with the duration from planting to sprouting. Further because tubers arrived at the storage locations on slightly different dates, it was also necessary to determine whether the effects of provenance and storage location on the date of sprouting can be accounted for by differences in the date of the start of storage or the duration from storage to sprouting.

The duration from planting to sprouting was significantly affected by provenance $(\mathrm{p}=0.001)$ and storage location $(p=0.001)$ but not their interaction. The duration from planting to sprouting was $288 \mathrm{~d}$ for tubers originating from GS. The duration from planting to sprouting was $22 \mathrm{~d}$ longer for tubers originating from HF than those from GS (Table 2) while it was $23 \mathrm{~d}$ longer for tubers from TS compared to those from GS. There was no significant difference in the duration from planting to sprouting in HF tubers compared to TS tubers. The fact that planting was done $24 \mathrm{~d}$ later at GS compared to $\mathrm{HF}$ or $\mathrm{TS}$ indicated that the $22 \mathrm{~d}$ shorter duration to sprouting observed at GS was associated with the duration from planting to sprouting. Thus the duration from planting to spouting in this case may not clearly reflect the effects of provenance.

The effect of provenance on the duration from storage to sprouting showed that tubers from the GS had the longest (74 d) mean duration from storage to sprouting (Table 3). Compared to tubers from the GS, the duration from storage to sprouting was significantly shorter by 4 and $8 \mathrm{~d}$ for tubers originating from $\mathrm{TS}$ and $\mathrm{HF}$ respectively. The fact that storage began $6 \mathrm{~d}$ later for tubers originating from $\mathrm{HF}$ compared to those from GS suggests that storage date was confounded in provenance.

In contrast, the effect of storage location on the duration from planting to sprouting showed that the duration was significantly $(\mathrm{p}=0.001)$ shorter by $10 \mathrm{~d}$ if tubers were stored at Onne (HF) compared to storage at Abuja (GS) (Table 4). Although planting was done on the same dates at Onne and Ibadan, the duration from planting to sprouting was $5 \mathrm{~d}$ 
shorter at Onne $(p=0.05)$ compared to Ibadan. Similarly, the effect of storage location on the duration from storage date to sprouting showed that storage at Abuja resulted in the longest duration to sprouting, with sprouting occurring after a mean of $74 \mathrm{~d}$ (Table 4). Compared with storage at Abuja, storage at Ibadan and Onne resulted in 4 and $9 \mathrm{~d}$ shorter durations to sprouting respectively. Date of start of storage was not confounded in storage location since the average start date of storage varied by only 1 to $2 \mathrm{~d}$.

Thus, storage location affected the duration from planting to sprouting by 4 and $8 \mathrm{~d}$ while storage location affected the duration from storage to sprouting by the 4 to $9 \mathrm{~d}$. in contrast, provenance did not significantly affect the duration from planting to sprouting or the duration from storage to spouting.

Table 3. Effect of provenance on the duration from planting to sprouting and the duration from storage to sprouting.

\begin{tabular}{|c|c|c|c|c|c|c|}
\hline & Duration from planti & routing & & Duration from storage to sprouting & & \\
\hline Provenance & Planting date (DOY) & Mean (d) & SE & Average days in storage (DOY) & Mean(d) & SE \\
\hline GS & 136 & 288 & 0.62 & 351 & 74 & 0.62 \\
\hline TS & 112 & 311 & 0.66 & 354 & 70 & 0.66 \\
\hline $\mathrm{HF}$ & 112 & 310 & 0.51 & 357 & 66 & 0.51 \\
\hline
\end{tabular}

Table 4. Effect of storage location on the duration from planting to sprouting and the duration from storage to sprouting.

\begin{tabular}{|c|c|c|c|c|c|c|}
\hline & Duration from plantir & routing & & Duration from storage to sprouting & & \\
\hline Provenance & Planting date (DOY) & Mean (d) & SE & Average days in storage (DOY) & $\operatorname{Mean}(d)$ & SE \\
\hline Abuja & 136 & 308 & 0.62 & 355 & 74 & 0.62 \\
\hline Ibadan & 112 & 303 & 0.61 & 354 & 70 & 0.61 \\
\hline Onne & 112 & 298 & 0.57 & 353 & 66 & 0.57 \\
\hline
\end{tabular}

\section{Discussion}

The yam belt of Nigeria, cuts across, from the North to the South, three distinct agro-ecological zones; Guinea savannah, Forest savannah transition and the Rainforest [12], which vary in latitude, rainfall pattern/start and duration of the rainy and dry seasons, solar radiation and photoperiod. This study followed a carefully planned method to determine whether the differences in duration to sprouting within the species of D. rotundata was caused by differences in tuber provenance and storage agroecology

This study is one study that evaluated the sprouting date of a very large number (over five thousand tubers) of $D$. rotundata tubers, and it was clear that the duration to sprouting which is an important indication of the duration of visible dormancy is highly plastic. This duration could be as long as $<311 \mathrm{~d}$ (as in this study) when considered as a duration from planting, between the months of April and early May, to sprouting or as short as $<74 \mathrm{~d}$ when considered as a duration from storage in mid-December to sprouting. Furthermore, the fact that a small (less than $6 \mathrm{~d}$ ) difference in start dates can lead to statistical significant result emphasizes the need to have uniform start dates across treatments. Thus, yam dormancy studies that evaluate the duration of visible dormancy must provide adequate information on the start date, preferably in days of the year (DOY), for the evaluation of duration of dormancy.

This study also found that differences in the duration from a defined planting date to sprouting or from a defined start of storage to sprouting in $D$. rotundata is not significantly influenced by tuber provenance. Indeed, the variation in date of sprouting was greater among landraces (up to $37 \mathrm{~d}$ ) within a provenance than among provenances ( 1 to $2 \mathrm{~d}$ ). The mean date of sprouting among provenance groups ranged from 55 to 57 DOY and it followed the order GS $>$ TS $>$ HF. The uniformity in sprouting date among provenance and presence of landraces with early and late sprouting times indicated that, though the 20 landraces used in this study were collected from different agroecologies, which vary in the timing of the start and length of growing seasons, there was no clear evidence to suggest that they were developed due to adaptation to the lengths of the wet-growing and dry-storage period at the various agroecologies. Thus while variations in sprouting date among yam species may be due to differences in agroecology of origin ([6], [8], [13), the difference among landraces within the species of $D$. rotundata may not be related to differences in agroecology of origin within Nigeria. The next question would be are the landraces used in this study truly specific to the respective agroecologies? This question can best be ascertained through molecular analysis. However, this study has assumed that they are specific to the respective agroecologies because their local names depict their origin. Further, their popularity among farmers in the various agroecological zones suggested that they are well known. In support of this, is the report of Okoli, 1980 [14], which said that the landrace 'Ekpe' is adapted to Anambra State in South-east Nigeria, and in this study 99-14 is described as 'Ekpe' and was collected from Anambra State in the HF. The presence of both early and late sprouting landraces among provenances supports the suggestion of Alexander and Coursey, 1969 [15] that farmers have selected for varieties with varied sprouting dates to meet their short and long term need of the tuber. The evolution of $D$. rotundata suggests that it is the result of hybridization between a rain forest species, D, cayenensis with short dormant period due to short dry season, and a wild species from the Guinea savanna with slightly longer dormant period due to longer dry season [8]. Therefore, it is proposed that the presence of landraces with varying dates of sprouting may have developed due to differences in the genes for length of dormancy or difference in the dominance of the genes 
selected for by farmers.

Results from thousands of tubers evaluated in this study showed that the earliest time of sprouting occurred in late December, but mostly within the first three months of the year ([16], [17], [18]). The occurrence of sprouting at a defined period or season (at end of the Harmattan season to the beginning of the rains) in the year in Nigeria such as between late December of previous year and April of the next year, suggests that landraces have developed life cycles/stages that fit the annual seasonal cycle. More specifically, the fact that sprouting is not restricted to beginning in April or May which marks the onset of the rains in the GS for example, negates the suggestion that the time of sprouting coincides with the onset of the rainy season and the time of planting ([19], [20]) per se. It is therefore suggested that it is not the actual start of the growing season that is the cue to start sprouting in Ibadan or Abuja particularly but rather that landraces have adapted or developed life cycles that fit the annual seasonal cycle and that sprouting always occurs before the onset of the rains because they have internal mechanism(s) that determine the onset of the next growing season. Okoli, 1980 [14] and Degras, 1993 [13] have long ago suggested also that the timing of the end of dormancy/start of sprouting is regulated by an endogenous biological 'clock'.

The effect of storage environment (in the barn or controlled environment facility) on yam dormancy is known but the effect of storing tubers in agroecologies other than their adapted one have not been investigated. In contrast to provenance, storage agroecology affects the duration of sprouting. Sprouting was earliest at Onne and latest at Abuja with Ibadan being intermediate. Generally, sprouting was 10 $\mathrm{d}$ earlier if tubers were stored at Onne compared to storage at Abuja Therefore, date of sprouting was clearly dependent on inherent genetic makeup of the landraces and the agroecology where they are stored, with Onne being more favorable for early sprouting. Earlier sprouting was probably encouraged at Onne due to the 1 to $2{ }^{\circ} \mathrm{C}$ warmer average storage temperatures [21] and higher relative humidity than that at Abuja [22]. The rate of progress of plant developmental events has been shown severally to increase with increasing temperature up to the optimum temperature for the process [1]. In the past, temperature has also been shown to affect the duration to sprouting in yam. It has been shortened by 10 to $16 \mathrm{~d}$ by storing tubers at $30{ }^{\circ} \mathrm{C}$ compared to $20{ }^{\circ} \mathrm{C}$ [17]. The effect of temperature is further enhanced when high temperatures of 30 to $35{ }^{\circ} \mathrm{C}$ are combined with high relative humidity in the range 70 to $80-85 \%$ ([22], [17]) Therefore, the small $(10 \mathrm{~d})$ degree of effect of storage agroecology on date of sprouting indicated that the effects of storage location on date of sprouting may be related to their ability to affect the progress of Phase 2 of dormancy [23].

\section{Conclusion}

In summary, this study has shown that the differences in the date of sprouting between landraces within the species of
D. rotundata were not be due to differences in their agroecology of origin, because landraces with early and late sprouting time are present at all agroecologies, but rather due to their storage agroecologies.

\section{References}

[1] Roberts, E. H. and Summerfield, R. J. (1987). Measurement and Prediction of Flowering in Annual Crops. In: Manipulation of Flowering (eds J. G. Atherton), pp.17-50. Butterworths, London.

[2] Roberts, E. H. and Summerfield, R. J. (1987). Measurement and Prediction of Flowering in Annual Crops. In: Manipulation of Flowering (eds J. G. Atherton), pp.17-50. Butterworths, London.

[3] Leopold, C. A. (1996). Natural History of Seed Dormancy. In: Plant Dormancy: Physiology, Biochemistry and Molecular Biology (ed G. A. Lang), pp.3-16. CAB International, Wallingford.

[4] Lang, A. (1952). Physiology of flowering. Annual Review of Plant Physiology, 3, 265-306.

[5] Lang, G. A., Early, J. D., Martin, G. C. and Darnell, R. (1987). Endo-, para-, and ecodormancy: physiological terminology and classifications for dormancy research. HortScience, 22, 371-377.

[6] Passam, H. C. (1982). Dormancy of Yams in Relation to Storage. In: Yams- Ignames (eds J. Miege and N. Lyonga), pp.285-293. Oxford: OUP.

[7] IITA, (1997). Project 13-Improvement of Yam-base Systems. Annual Report 1997. IITA Ibadan, Nigeria.

[8] Barker, D. J., Keatinge, J. D. H. and Asiedu, R. (1999). Yam dormancy: potential mechanisms for its manipulation. Tropical Science, 39, 168-177.

[9] Coursey, D. G. (1976). The Origins and Domestication of Yams in Africa. In: Origins of African Plant plant Domestication (ed. J. R. Harlan), pp.383-408. Mouton, La Hague.

[10] Coursey, D. G. (1967). Yams. Longmans, Green and Co. Ltd, London

[11] Ile, E. I. (2004). Control of Tuber Dormancy and Flowering in Yam (Dioscorea rotundata Poir.) tuber. PhD thesis, The University of Reading, Reading UK.

[12] Orkwor, G. C. (1998). The importance of yams. In: Food Yams: Advances in Research (eds G.C. Orkwor, R. Asiedu and I. J. Ekanayake), pp. 1-12. NRCRI and IITA, Ibadan, Nigeria.

[13] Degras, L. (1993). The Yam: A Tropical Root Crop. (ed R. Costo). MacMillan, London.

[14] Okoli, O. O. (1980). Dry matter accumulation and tuber sprouting in yams Dioscorea spp.). Experimental Agriculture, $16,161-167$.

[15] Alexander, J. and Coursey, D. G. (1969). The Origins of Yam Cultivation. In: The Domestication and Exploitation of Plants (eds P. J. Ucko and G. W. Dimbleby), pp. 405- 425. London: Duckworth. 
[16] Arnolin, R. (1982). Vegetative Cycle of the Yam D. alata cv. Tahiti and Belep: Influence of Spaced Planting. In: Proceedings $18^{\text {th }}$ Annual Meeting, Caribbean Food Crops Society, Mayaguez, Puerto Rico University, Puerto Rico. pp.146-169. Caribbean Food Crops Society

[17] Swanell, M. C., Wheeler, T. R., Asiedu, R. and Craufurd, P. Q. (2003). Effect of harvest date on the dormancy period of yam (Dioscorea rotundata). Tropical Science 2003, 43, 103-107.

[18] Shiwachi, H., Ayankanmi, T., Asiedu, R. and Onjo, M. (2003). Induction of germination in dormant yam (Dioscorea spp.) tubers with inhibitors of gibberellins. Experimental Agriculture, 39, 209-217.

[19] Njoku, E. (1963). The propagation of yams Dioscorea spp. by vine cuttings. Journal of West African Science Association, 18, 29-32.
[20] U.S.D.A, (United States Departments of Agriculture) (1972). Yam Production Methods. In: Production Research Report No. 147. U.S.D.A. USA.

[21] Passam, H. C. (1977). Sprouting and apical dominance of yam tuber. Tropical Science, 19, 29- 39.

[22] Mozie, O. (1984). Influence of ventilation and humidity during storage on weight and quality changes of white yam tubers Dioscorea rotundata Poir. Journal of the University of Puerto Rico, 68, 341-348.

[23] Ile, E. I. P. Q. Craufurd, N. H. Battey and R. Asiedu (2006). Phases of tuber dormancy in yam (Dioscorea rotundata Poir.), Annals of Botany 97; 497-504. 